\title{
STIMULATORY EFFECTS OF CREATINE ON METABOLIC ACTIVITY, DIFFERENTIATION AND MINERALIZATION OF PRIMARY OSTEOBLAST-LIKE CELLS IN MONOLAYER AND MICROMASS CELL CULTURES
}

\author{
I. Gerber ${ }^{1 *}$, I. ap Gwynn², M. Alini ${ }^{3}$ and T. Wallimann ${ }^{1}$ \\ ${ }^{1}$ Institute of Cell Biology, ETH Hoenggerberg, CH-8093 Zurich, Switzerland \\ ${ }^{2}$ Biological Sciences, The University of Wales, Aberystwyth, Ceredigion SY23 3DA, Wales, U.K. \\ ${ }^{3} \mathrm{AO}$ Research Institute, Clavadelerstrasse, CH-7270 Davos Platz, Switzerland
}

\begin{abstract}
Abbreviations used
ALP: alkaline phosphatase; BMD: bone mineral density; CK: creatine kinase; Cr: creatine; GPA: b-guanidinopropionic acid; MTT: 3-(4,5-dimethylthiazol-2-yl-)-2,5-diphenyltetrazoliumbromide; NR: neutral red; PCr: N-phospho-creatine; TEM: transmission electron microscopy
\end{abstract}

\begin{abstract}
The effects of creatine $(\mathrm{Cr})$ supplementation on primary rat osteoblast-like cells cultured as monolayer and micromass were investigated. Cr was added to the medium at concentrations of either 10 or $20 \mathrm{mM}$. At various time points, the cell cultures were analyzed morphologically, metabolically and biochemically.

The degree of differentiation of primary osteoblast-like cell cultures was higher in micromass cultures compared to monolayer cultures, as judged by alkaline phosphatase (ALP) activity and extent of mineralization. In both culture systems, $\mathrm{Cr}$ supplementation showed positive effects, which were dependent on the organizational level of the osteoblast-like cells in such a way that the cells in monolayer culture showed significantly increased metabolic activity, ALP activity and mineralization in the presence of $\mathrm{Cr}$ than without the supplement. In micromass cultures, $\mathrm{Cr}$ also significantly enhanced ALP activity and mineralization, without affecting metabolic activity. The effect of $\mathrm{Cr}$ on ALP activity was more pronounced at higher concentrations of $\mathrm{Cr}$, but $20 \mathrm{mM} \mathrm{Cr}$ already showed some adverse effects on cell viability. In conclusion, chemically pure $\mathrm{Cr}$ added to low serum cell culture medium has a stimulatory effect on metabolic activity, differentiation and mineralization of osteoblast-like cells indicating that $\mathrm{Cr}$ supplementation could also be used as a potential clinical intervention to stimulate cell growth, differentiation and mineralization during bone repair in vivo.
\end{abstract}

Key Words: Osteoblast-like cells, creatine, viability, metabolic activity, ultrastructure, differentiation, mineralization, monolayer culture, micromass culture, cell protection.

*Address for correspondence:

Isabel Gerber

Institute of Cell Biology

ETH Hoenggerberg

CH-8093 Zurich, Switzerland;

Telephone Number: ++41-(0)44-6333942

FAX Number: ++41-(0)44-6331069

e-mail: isabelle.gerber@cell.biol.ethz.ch

\section{Introduction}

Creatine $(\mathrm{Cr})$ occurs naturally in the human body and is partly synthesised by the kidney, pancreas and liver (approximately 1-2 grams per day), and partly ingested with food (approximately 1-5 grams per day), especially with meat and fish (for review see Wyss and Wallimann, 1994; Wyss and Kaddurah-Daouk, 2000). Cr and the enzyme Cr kinase (CK) occur mainly in skeletal and heart muscle, brain, retina and testes (Wallimann and Hemmer, 1994), but are also present in smooth muscle, growing bone and cartilage, as well as in immune cells (Wallimann, et al., 1992). Cr is taken up into these cells by a $\mathrm{Cr}$ transporter (CreaT) (for review see Guerrero-Ontiveros and Wallimann, 1998; Wyss and Kaddurah-Daouk, 2000). Within the cell, a phosphate group from ATP is transferred to $\mathrm{Cr}$ with the help of $\mathrm{CK}$, thus forming high-energy phospho- $\mathrm{Cr}(\mathrm{PCr})$. The large pool of $\mathrm{PCr}$ acts as an energy storage to resynthesise ATP (adenosin-triphosphate) from ADP (adenosin-diphosphate). Besides its function as a temporal energy buffer, $\mathrm{PCr}$ also acts as spatial energy buffer to shuttle high-energy phosphates between mitochondria and cellular ATP utilisation sites (Wallimann et al., 1992; Wyss and Wallimann, 1994).

For the development of normal bone and cartilage and during bone repair, cells require energy to survive, proliferate, differentiate and synthesize extracellular matrix, which then mineralizes. During these processes, ATP is generated by glycolysis, oxidative phosphorylation, as well as via the $\mathrm{CK} / \mathrm{PCr}$ system present in these cells (Sjovall and Hansson, 1971; Somjen et al., 1984c); for review see Wallimann and Hemmer (1994). Thus, CK is not only present in excitable tissues, like muscle, heart and brain cells, where the $\mathrm{CK} / \mathrm{PCr}$ system plays an important role for cellular bioenergetics (Wallimann et al., 1992), but is also present in cartilage and bone (Granstrom, 1986; Funanag et al., 1992; Rajpurohit et al., 1998). Dependent on the developmental stage of cartilage and bone, different $\mathrm{CK}$ isoforms are expressed at various levels, indicating an important role of $\mathrm{CK}$ and $\mathrm{PCr}$ for cartilage and bone development, differentiation and function in general (Katoh et al., 1991; Pollesello et al., 1991; Kvam et al., 1992; Shapiro et al. 1992; Wallimann and Hemmer, 1994; Hobson et al., 1999). 
Resting and hypertrophied cartilage both contain PCr in the range of 0.1 to $0.4 \mathrm{nmole} / \mu \mathrm{g}$ DNA (Shapiro et al., 1992), but the highest amount of $\mathrm{PCr}$ (around $1.8 \mathrm{nmole} / \mu \mathrm{g}$ DNA) is found in the proliferative zone of cartilage. In the transition zone of calcified cartilage and bone, no $\mathrm{PCr}$ is detectable. On the other hand, the highest content of $\mathrm{Cr}$ is found in resting cartilage (around $34 \mu \mathrm{mole} / \mu \mathrm{g}$ DNA), whereas the other zones all contain lower amounts of $\mathrm{Cr}$ (around 14-18 $\mu$ mole/ $\mu$ g DNA) (Katoh et al., 1991; Shapiro et al., 1992). Chondrocytes undergoing hypertrophy in vitro and in vivo show an increase in CK activity (Katoh et al., 1991; Shapiro et al., 1992; Hobson et al., 1999). There is also an increase in CK activity from resting-proliferative cartilage to hypertrophic cartilage ( 6 fold) and the transition zone of calcified cartilage and bone (17 fold) (Katoh et al., 1991; Shapiro et al., 1992). In addition, during cartilage calcification, there is an elevation in $\mathrm{PCr}$ turnover because the $\mathrm{PCr}$ concentration in calcified cartilage is low and the activity of the CK in this zone is high (Shapiro et al., 1992). Thus, CK activity seems to be required for matrix synthesis and mineralization in the growth plate cartilage (Funanage et al., 1992). There is evidence that chondrocytes and osteoblasts require large amounts of energy during mineralization (Cartier, 1969; Heyden and From, 1970; Kakuta et al., 1986; Shapiro et al., 1988; Pollesello et al., 1991; Komarova et al., 2000). In addition, maximal activity of ATPases is observed at the onset of matrix deposition, followed by a decrease of enzyme activities during the transformation of osteoblasts to mature osteocytes and at the time of chondrocytes hypertrophy (Heyden and From, 1970). During bone development, CK enzyme activity peaks in diaphyseal bone and cartilage in rats of peripubertal age (Somjen et al., 1994). In bone, similar to cartilage, CK is also experimentally increased both in vitro and in vivo by insulin growth factor I (Somjen and Kaye, 1994); by 1,25dihydroxyvitamin $D_{3}$ (Somjen et al., 1984a; Somjen et al., 1984b); by parathyroid hormone (PTH) (Somjen et al., 1985a; Somjen et al., 1985b; Somjen et al., 1987; Kaye et al., 1990); by protease-resistant variants of PTH (Somjen et al., 1995); by prostaglandin $\mathrm{E}_{2}$ (Somjen et al., 1985a; Somjen et al., 1985b); by 17b-estradiol (Gray, 1989; Kaye et al., 1990). Furthermore, the stimulation of bone cell energy metabolism by $17 \mathrm{~b}$-estradiol and testosterone is sex specific (Somjen et al., 1991). Interestingly, the amount of bone produced during heterotropic bone formation by implantation of bone morphogenetic protein into the muscle of rats shows an almost parallel relationship to the level of CK (Ono et al., 1994).

Cr supplementation, first employed by athletes to enhance muscle mass, power and performance (Mujika and Padilla, 1997), is increasingly recognized as a potentially important adjuvant therapeutic agent for patients with different muscle diseases, like muscle dystrophy, muscle disuse atrophy, as well as other neuromuscular and neurodegenerative diseases, like ALS, Huntington etc. (Tarnopolsky and Parise, 1999; Vorgerd et al., 2000; Walter et al., 2002; Bender et al., 2005) (for reviews see Wallimann et al., 1999; Wyss and Kaddurah-Daouk, 2000; Wyss and Schulze, 2002; Baker and Tarnopolsky, 2003; Persky et al., 2003). Cr supplementation increases not only the pool of free Cr, but also that of PCr (Ipsiroglu et al., 2001). Positive effects of $\mathrm{Cr}$ on regaining muscle mass and strength have been reported in rehabilitation of human subjects after immobilization (Hespel et al., 2001). Furthermore, in a recent double-blinded clinical study with young patients suffering from muscular dystrophy, the bone mineral density increases on average by $3 \%$ and bone resorption was reduced by $30 \%$ as a "side effect" in the Cr treated group (Louis et al., 2003). This shows that $\mathrm{Cr}$ may have direct beneficial effects on BMD (bone mineral density) or indirectly by affecting bones by increasing muscle strength.

In an attempt to show whether the energy stored in $\mathrm{PCr}$ could be used directly for bone mineralization, very crude preparations of $\mathrm{PCr}$ or mixtures of $\mathrm{PCr}$ and $\mathrm{Cr}$ at concentrations of $10^{-4} \mathrm{M}$ have been added earlier directly to cultured embryonic chicken femora, a treatment which suggested a stimulatory effect on the mineralization of cartilage matrix in the epiphysis and the perichondrium of the diaphysis of these femora (Saito, 1959). In addition, $\mathrm{PCr}$ seemed to promote mineralization in differentiating chick limb bud mesenchymal cells in micromass cultures at a concentration of $2 \mathrm{mM}$ (Boskey et al., 1994).

Therefore, we wanted to study the effects of supplementing the culture media with chemically pure $\mathrm{Cr}$ on proliferation, differentiation and mineralization of osteoblast-like cells in monolayer and micromass cultures under controlled conditions.

The parameters investigated were viability based on the physical uptake of neutral red (NR) and metabolic activity by MTT (3-(4,5-dimethylthiazol-2-yl-)-2,5diphenyltetrazoliumbromide). The MTT assay and the neutral red uptake are widely accepted to assess viability and growth of cells including osteoblasts in biocompatibility and cytotoxicity studies (Mosmann, 1983; Fini et al., 2001; Ramires et al., 2001; Aldini et al., 2002; Ciapetti et al., 2002; Yang et al., 2002; Torricelli et al., 2003). Differentiation was studied by morphological parameters such as histochemical staining for alkaline phosphatase (ALP) activity and degree of mineralization, as well as ultrastructure observed by transmission electron microscopy (TEM). As biochemical parameters ALP activity, DNA and protein content were measured at different time points in cell cultures with and without the addition of $\mathrm{Cr}$.

\section{Materials and Methods}

\section{Materials}

All tissue culture disposable materials were purchased from Falcon (Becton Dickinson AG, Basel, Switzerland). Fetal calf serum and growth media were purchased from Gibco (Invitrogen, Basel, Switzerland). All chemicals were purchased from Fluka (Buchs, Switzerland), when not stated otherwise.

\section{Methods}

Enzymatic cell isolation. Parietal and frontal calvariae (4 per animal) were explanted aseptically from 6 day old IcoIbm rats. The calvariae were placed in Tyrode's 
buffered salt solution calcium- and magnesium-free (TBSS). The periosteum and endosteum were removed enzymatically by treatment in $0.05 \%$ trypsin $(1: 250$; Sigma, Buchs, Switzerland) and $0.02 \%$ collagenase A $(0.76 \mathrm{U} / \mathrm{mg}$; Roche Diagnostics, Rotkreuz, Switzerland) dissolved in TBSS (40 calvaria $/ 20 \mathrm{ml}$ ). The calvariae were shaken for 70 minutes in a water bath at $37^{\circ} \mathrm{C}$. They were washed with TBSS and then transferred to $60 \mathrm{~mm}$ culture dishes (40 calvariae/dish) containing $5 \mathrm{ml}$ of $0.02 \%$ collagenase A $(0.76 \mathrm{U} / \mathrm{mg})$ in culture medium BGJ $\mathrm{b}_{\mathrm{b}}$ Fitton Jackson modification and placed in the incubator for 3 hours. After the second collagenase treatment the remaining calvariae were washed with culture medium supplemented with $10 \%$ fetal calf serum (FCS). The calvariae were transferred into $60 \mathrm{~mm}$ culture dishes (4 frontal and 4 parietal $/ 60 \mathrm{~mm}$ dish). The growth medium, supplemented with $10 \%$ FCS and $50 \mu \mathrm{g} / \mathrm{ml}$ ascorbate, was changed completely every $48 \mathrm{~h}$. The explant cultures were kept for 3 weeks. After 3 weeks the migrated cells, along with the calvariae, were treated with enzymes to harvest the cells. The dish was washed with TBSS and $5 \mathrm{ml}$ of TBSS containing $0.05 \%$ trypsin and $0.02 \%$ collagenase A $(0.76 \mathrm{U} / \mathrm{mg})$ was added. After 1 hour in the incubator, the dish was washed with culture medium supplemented with $10 \%$ FCS. The cells obtained were filtered through a $40 \mu \mathrm{m}$ nylon mesh to remove bone debris and cell aggregates. The suspended cells were centrifuged at $600 \mathrm{~g}$ for 5 minutes. The cell pellet was resuspended in serum containing medium and centrifuged. The viability of the resuspended cells was examined by the 'dye exclusion' of $0.4 \%$ trypan blue and the vital cells counted using a haemocytometer. The inoculation densities were $2 \cdot 10^{5}$ cells/ $10 \mathrm{~cm}^{2}$ for monolayer and $2 \cdot 10^{5} / 30 \mu 1 / 10 \mathrm{~cm}^{2}$ for micromasses for all performed experiments. The micromass cultures were kept for 30 minutes in the incubator before $2 \mathrm{ml}$ growth medium was added. After 4 days, the growth medium was completely removed. The control groups were kept in $4 \mathrm{ml} \mathrm{BGJ} \mathrm{b}_{\mathrm{b}}$ supplemented with $1 \%$ FCS and $50 \mu \mathrm{g} /$ $\mathrm{ml}$ ascorbate. In the experimental groups, the growth medium was additionally supplemented with either $10 \mathrm{mM} \mathrm{Cr}$ or $20 \mathrm{mM} \mathrm{Cr}$. All the cultures were kept at $37^{\circ} \mathrm{C}$ in a humidified atmosphere of $5 \% \mathrm{CO}_{2}$ and $95 \%$ air. All culture media were supplemented with $50 \mu \mathrm{g} / \mathrm{ml}$ ascorbate. To increase plating efficiency, during cell isolation and inoculation, no ascorbate was used (Burks and Peck, 1979). No antibiotics, or antimycotics, nor b-glycerophosphate were added. The media ( $4 \mathrm{ml} / 35 \mathrm{~mm}$ culture dish) were changed completely twice a week.

Light microscopy. After 1,2 and 3 weeks the cultures were stained histochemically for the alkaline phosphatase, using the Sigma Kit no. 85L. As a result, an insoluble, visible blue pigment is formed at sites of phosphatase activity. The deposition of calcium phosphate, at 2 and 3 weeks, was determined by von Kossa staining. A photograph was taken from the center of each culture dish under a Wild M400 macroscope. The mineralization (black deposits) in an area of $123 \mathrm{~mm}^{2}$ was quantified by a Kontron IMCO 1000 image analyser.
Transmission electron microscopy (TEM). At 3 weeks, the cell cultures were fixed with $2.5 \%$ glutaraldehyde in $0.1 \mathrm{M}$ cacodylate buffer $\mathrm{pH} 7.4$ for $20 \mathrm{~min}$, postfixation in $1 \% \mathrm{OsO}_{4}$ in $0.1 \mathrm{M}$ cacodylate buffer $\mathrm{pH} 7.4$ for $1 \mathrm{~h}$ at $4^{\circ} \mathrm{C}$, then $2 \%$ aqueous uranyl acetate for $1 \mathrm{~h}$ at room temperature; dehydration in an ethanol series and embedding in LR White (London Resin Co, Basingstoke, U.K.). Ultrathin sections through the nodular area of monolayer cultures were cut with a Drukker Diamond knife (Drukker International, Cuijk, The Netherlands) on a LKB III Microtome (LKB, Bromma, Sweden) and stained with $2 \%$ uranyl acetate and lead citrate (Reynolds, 1963). Osmium rich regions, i.e., the nodules in the monolayer, and the centers of the micromass cultures, were selected respectively. The sections were examined using a JEOL (Tokyo, Japan) JEM 100CX transmission electron microscope operated at $100 \mathrm{kV}$.

Viability. At 1, 2, and 3 weeks, the viability of the cells was determined by using the neutral red method (Lindl and Bauer, 1994). The cells were incubated in $2 \mathrm{ml} / 10 \mathrm{~cm}^{2}$ neutral red solution $(0.5 \mathrm{mg}$ neutral red $/ \mathrm{ml}$ growth medium) at $37^{\circ} \mathrm{C}$ for $3 \mathrm{~h}$. After rinsing the cells with PBS, the dye was extracted by addition of $4 \mathrm{ml} / 10 \mathrm{~cm}^{2}$ extraction buffer $(50 \%$ ethanol in $1 \%$ acetic acid) on a shaker. The absorbance of the supernatant was read at $540 \mathrm{~nm}$ versus extraction buffer in a Lambda 12 spectophotometer from Perkin Elmer (Rotkreuz, Switzerland).

Metabolic activity. At 1, 2, and 3 weeks, the metabolic activity was analyzed by using the Boehringer 'Cell Proliferation Kit I (MTT)' (Roche Diagnostics) and DMSO (dimethylsulfoxide) as solvent (Hoffman, 1994). The MTT Stock $(5 \mathrm{mg} / \mathrm{ml}$ in sterile PBS) from Boehringer was diluted 1:10 with complete growth medium and the cells were incubated in $2 \mathrm{ml} / 10 \mathrm{~cm}^{2}$ MTT solution at $37^{\circ} \mathrm{C}$ for $3 \mathrm{~h}$. Then, MTT crystals were resolved in $4 \mathrm{ml} / 10 \mathrm{~cm}^{2}$ dimethylsulphoxide (DMSO) on a shaker. The absorbance of the supernatant was read at $550 \mathrm{~nm}$ versus DMSO in a Lambda 12 spectophotometer.

Biochemistry. Whole cultures were washed at 1, 2 and 3 weeks with phosphate buffered saline (PBS) and $500 \mu \mathrm{l}$ $0.25 \mathrm{M}$ sucrose $/ 35 \mathrm{~mm}$ dish was added. The cells and the matrix were scrubbed off the dish and transferred into a cryotube and frozen at $-80^{\circ} \mathrm{C}$. Immediately before the assays, the cells were thawed and sonicated ( $3 \times 20 \mathrm{~s})$ at $70 \mathrm{~W}$ and $20 \mathrm{kHz}$ on ice. The samples were centrifuged at $600 \mathrm{~g}$ for $7 \mathrm{~min}$. to remove cell debris and the volume of the supernatant was determined. The samples were analyzed in a Perkin Elmer Lambda 12 Spectrophotometer, except for the DNA determination, which was obtained using a Hoefer TKO 100 MiniFluorometer (Hoefer Scientific Instruments, San Francisco, CA).

Alkaline phosphatase activity (ALP). We used Sigma Kit no. 245 for the quantitative, kinetic determination of alkaline phosphatase activity. 
Total protein. The Bio-Rad protein assay kit II (BioRad, Glattbrugg, Switzerland) was used with bovine serum albumin as standards.

DNA. A simple and rapid assay for quantitative DNA determination in crude homogenates was used (Labarca and Paigen, 1980). Each sample was diluted with $3 \mathrm{ml}$ of phosphate buffered saline, $\mathrm{pH} 7.4$ containing $2 \mathrm{M} \mathrm{NaCl}$ (DPBS) and sonicated as described above. Then aliquots were mixed with $0.1 \mu \mathrm{g} / \mathrm{ml}$ Hoechst 33258 (Aventis, Strasbourg, France) in DPBS and the fluorescence was read in a Hoefer TKO 100 Mini-Fluorometer.

Statistics. To compare the effect of the various growth media, contrast analyses of variance models were evaluated. Main effects and interaction effects were examined by F-Tests. 'Least Squares Means' (LS) were calculated to yield average means accounting for the other variables in the model. LS Means were compared by using Tukey's multiple range test. QQ-Plots of the residuals and Tukey-Anscombe plots (residuals x predicted) were analyzed to check for normal distribution assumption.

\section{Results}

\section{Viability and metabolic activity}

Quantitative analysis of the NR uptake as measure of cell viability in monolayer cultures showed a small but significant $(p<0.05)$ interaction effect (Fig. 1A), meaning that the effects of time and $\mathrm{Cr}$ treatment were not additive. There was an increase in the NR uptake in the control group and the $10 \mathrm{mM} \mathrm{Cr}$ group over culture time, which was less evident in the $20 \mathrm{mM} \mathrm{Cr}$ group. This was reflected by statistical analysis, where the control and the $10 \mathrm{mM} \mathrm{Cr}$ group had significantly ( $<<0.0002, p<0.0015$ respectively) lower values at 1 week than 3 weeks. There was no significant difference in the control and the $\mathrm{Cr}$ treated groups, except the $20 \mathrm{mM} \mathrm{Cr}$ group, which had significantly $(\mathrm{p}<0.008)$ lower values than the control group at 3 weeks. Similar results were obtained in the micromass cultures, which also had significantly $(\mathrm{p}<0.03)$ higher values for NR uptake at 2 weeks as compared to 1 week, but the values were similar at 2 and 3 weeks (Fig. 1B). The 20 mM Cr group was significantly $(\mathrm{p}<0.0002$, $\mathrm{p}<0.002$
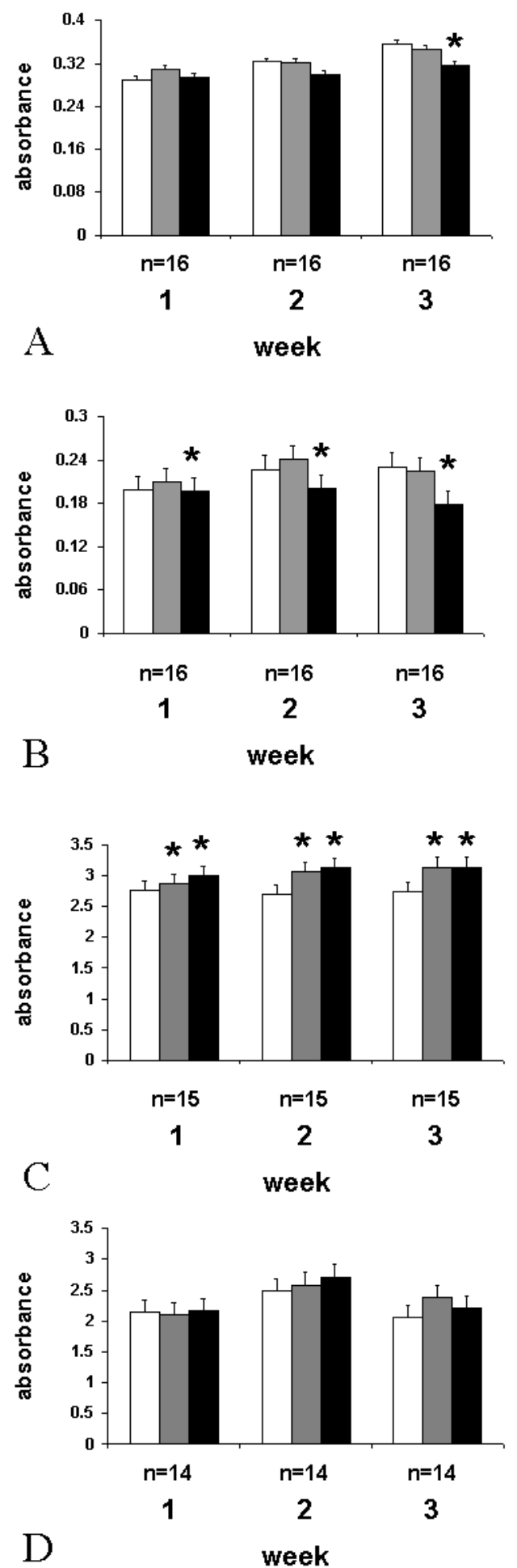

Figure 1. Quantitation of viability (NR) and metabolic activity (MTT) of osteoblast-like cells at 1, 2, and 3 weeks, cultured in the absence (control) and presence of $10 \mathrm{mM}$ or $20 \mathrm{mM}$ of creatine $(\mathrm{Cr})$. A: Viability by NR uptake in monolayer cultures. Note: significant $(p<0.05)$ interaction effect, meaning that the effects of time and Cr treatment were not additive; control group and $10 \mathrm{mM} \mathrm{Cr}$ groups were significantly lower $(\mathrm{p}<0.0002$ and $\mathrm{p}<0.0015$, respectively) at 1 week than at 3 weeks; control group significantly higher $(\mathrm{p}<0.008)$ than the $20 \mathrm{mM}$ Cr group at 3 weeks. B: Viability by NR uptake in micromass cultures. Note: Values at 2 weeks significantly $(\mathrm{p}<0.03)$ higher than at 1 week; $20 \mathrm{mM} \mathrm{Cr}$ values significantly lower $(\mathrm{p}<0.0002$ and $\mathrm{p}<0.002)$ than control and $10 \mathrm{mM} \mathrm{Cr}$ group. C: Metabolic activity by MTT conversion in monolayer cultures. Note: control group was significantly lower $(p<0.0002)$ than the both 10 and $20 \mathrm{mM} \mathrm{Cr}$ groups. D: Metabolic activity by MTT conversion in micromass cultures. Note: significantly $(p<0.0002)$ lower values at 1 week and 3 weeks than at 2 weeks. Control cells grown in medium with low serum concentration (white columns). Cells grown under the same conditions plus $10 \mathrm{mM} \mathrm{Cr}$ (grey columns) and cells grown with supplementation of $20 \mathrm{mM} \mathrm{Cr}$ (black columns). Data are expressed as least squares means $+1.96 \mathrm{x}$ standard error. 
respectively) lower than both the control and the $10 \mathrm{mM}$ $\mathrm{Cr}$ group, but the later ones were similar. These results with monolayer and micromass cultures demonstrate a significant increase in the number of viable cells during culture time and no negative effects on the viability by supplementation of the growth medium with $10 \mathrm{mM} \mathrm{Cr}$, but the higher concentration of $\mathrm{Cr}$ at $20 \mathrm{mM}$ had some adverse effects in both culture systems.

However, Cr revealed a clear positive treatment effect on the metabolic activity (MTT) in monolayer cultures (Fig. 1C). The control group was significantly $(\mathrm{p}<0.0002)$ lower than the both 10 and $20 \mathrm{mM} \mathrm{Cr}$ groups. There was no difference amongst the two $\mathrm{Cr}$ groups. The metabolic activity of the cells increased during culture time, but it was not significant. This was in contrast to micromass cultures, where the MTT activity peaked at 2 weeks, showing significantly $(p<0.0002)$ higher values than at 1 week and 3 weeks (Fig. 1D). The values at 1 and 3 weeks were similar. The control was slightly lower than the $\mathrm{Cr}$ groups, but the difference was non significant. These results show that effect of $\mathrm{Cr}$ supplementation on the metabolic activity did dependent on the culture system used meaning that only in monolayer cultures a clear stimulatory effect of $\mathrm{Cr}$ on the metabolic activity could be demonstrated. No adverse effect of $\mathrm{Cr}$ on the metabolic activity could be detected in both culture systems. The addition of $20 \mathrm{mM}$ $\mathrm{Cr}$, however, clearly reduced the number of viable cells in both culture systems, but it still stimulated the metabolic activity in monolayer cultures, which was less evident in the micromass cultures.

\section{Biochemistry}

There was a non-significant increase in the DNA content in all groups over time in monolayer cultures (Fig. 2A). The control was lower than the $\mathrm{Cr}$ groups, but the differences were non significant. This was in contrast to micromass cultures, where the values for the DNA content were comparable in all groups at all time points (Fig. 2B). Comparison of monolayer and micromass cultures revealed significantly $\mathrm{p}<0.0005$ ) higher values for monolayer than micromass cultures. So the addition of $\mathrm{Cr}$ had no adverse effects on the proliferation of the cells. Furthermore, proliferation of the cells was generally suppressed when the cells were cultured in an organoid system such as micormasses as compared to the standard monolayer cultures.

Differentiation of the cells in monolayer and micromass cultures, as measured by the ALP activity, significantly
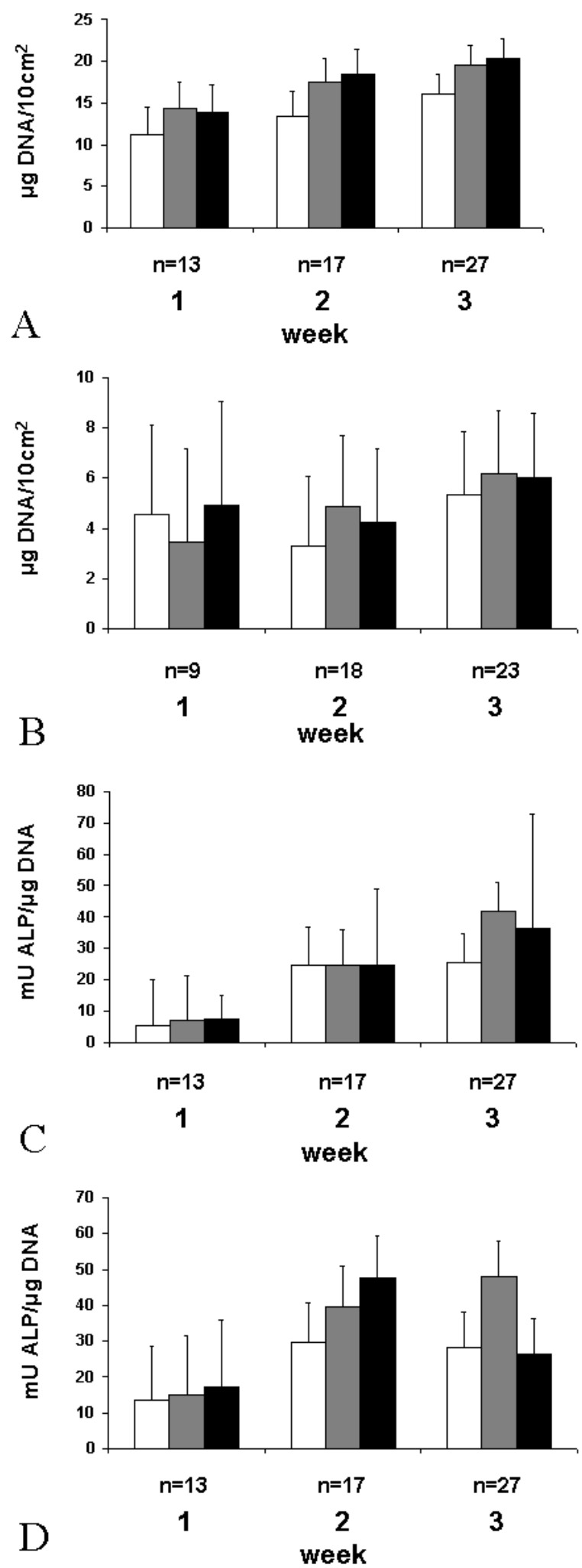

Figure 2. DNA content and ALP activity of osteoblast-like cells at 1, 2, and 3 weeks, cultured in the absence (control) and presence of $10 \mathrm{mM}$ or $20 \mathrm{mM}$ of creatine $(\mathrm{Cr})$. A: DNA content per dish in monolayer cultures. B: DNA content per dish in micromass cultures. Note: Monolayer significantly $(p<0.0005)$ higher values in total DNA than micromass. C: ALP activity normalized to DNA content in monolayer cultures. D: ALP activity normalized to DNA content in micromass cultures. Note: significantly $(p<0.0005)$ lower ALP activity in monolayer than in micromass; values for ALP activity at 2 and 3 weeks significantly higher $(\mathrm{p}<0.0001)$ than at 1 week; significant $(\mathrm{p}<0.025)$ stimulatory effect of $20 \mathrm{mM} \mathrm{Cr}$ as compared to control. Control cells grown in medium with low serum concentration (white columns). Cells grown under the same conditions plus $10 \mathrm{mM} \mathrm{Cr}$ (grey columns) and cells grown with supplementation of $20 \mathrm{mM} \mathrm{Cr}$ (black columns). Data are expressed as least squares means + standard error. 

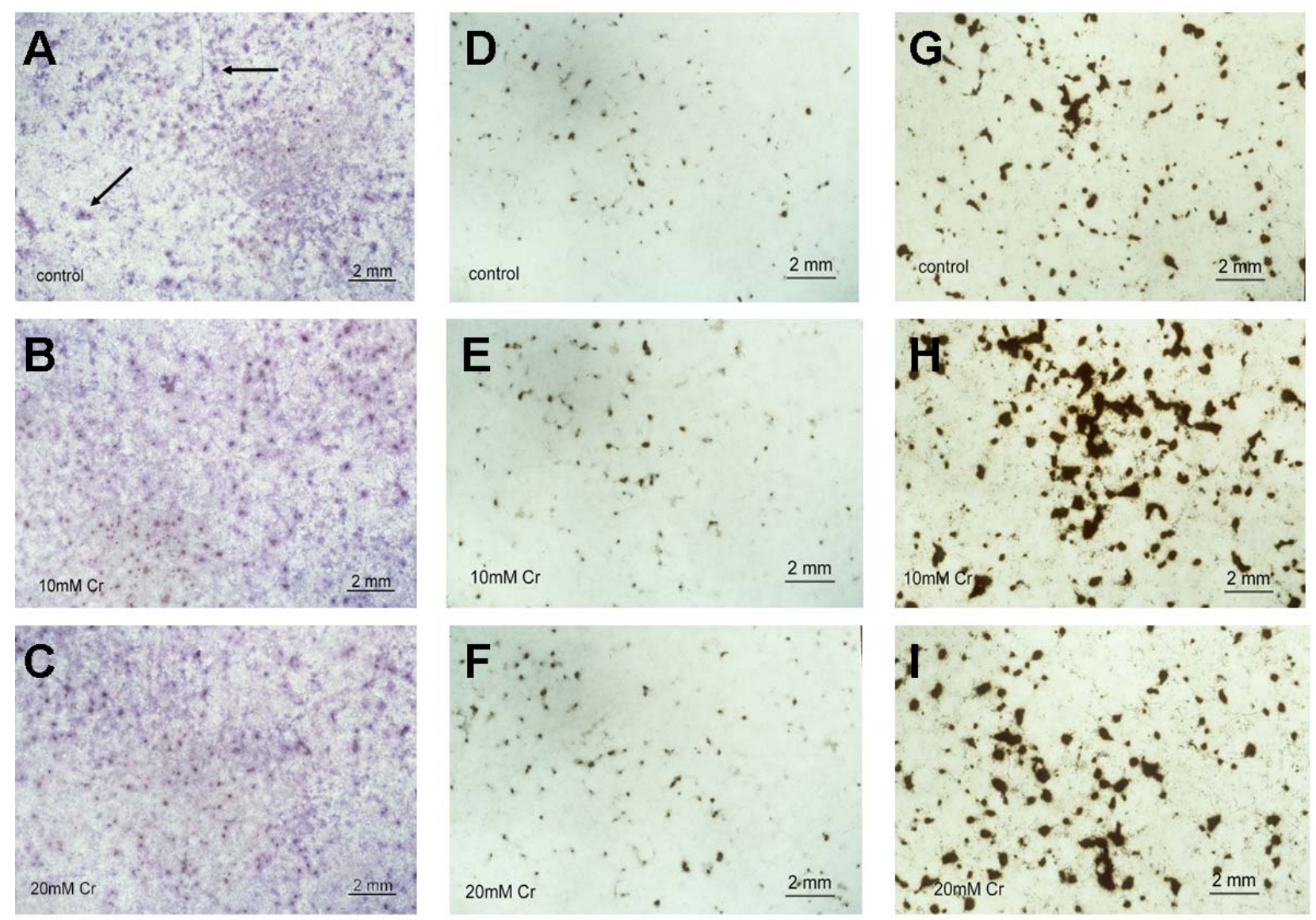

Figure 3. Histochemical staining of ALP activity and detection of calcification visualized by von Kossa staining in monolayer cultures of osteoblast-like cells at 2, and 3 weeks, cultured in the absence (control) and presence of $10 \mathrm{mM}$ or $20 \mathrm{mM}$ of creatine $(\mathrm{Cr})$. ALP activity is shown in blue and mineralization in black. There was no counterstaining of the cells. Note the staining is more pronounced in the Cr groups than in the control. Nodule formation (arrow). A: ALP activity of control group at 2 weeks. B: ALP activity of 10mM Cr group at 2 weeks. C: ALP activity of $20 \mathrm{mM} \mathrm{Cr}$ group at 2 weeks. D: Mineralization of control group at 2 weeks. E: Mineralization of $10 \mathrm{mM}$ Cr group at 2 weeks. F: Mineralization of $20 \mathrm{mM} \mathrm{Cr}$ group at 2 weeks. G: Mineralization of control group at 3 weeks. H: Mineralization of $10 \mathrm{mM}$ Cr group at 3 weeks. I: Mineralization of $20 \mathrm{mM}$ Cr group at 3 weeks.

( $p<0.0002, p<0.0001)$ increased from the first to the second week and remained similar thereafter (Figs. 2C, D). At 1 and 2 weeks in monolayer, all groups were rather similar, but at 3 weeks, the $\mathrm{Cr}$ treated groups were higher than the control (Figure 2C). In micromass cultures at 2 weeks, there was a dose dependent increase in ALP activity from control to 10 and $20 \mathrm{mM} \mathrm{Cr}$. At 3 weeks, only the $10 \mathrm{mM}$ $\mathrm{Cr}$ group was higher than the control, whereas the control and the $20 \mathrm{mM} \mathrm{Cr}$ group had similar values. Statistical analysis showed that ALP activity was significantly $(p<0.0002)$ lower at 1 week than at 2 and 3 weeks. In addition, there was an overall significant $(\mathrm{p}<0.025)$ stimulatory effect of $20 \mathrm{mM} \mathrm{Cr}$ as compared to control, whereas $10 \mathrm{mM} \mathrm{Cr}$ was comparable to the control. Furthermore, micromasses had significantly $(\mathrm{p}<0.0005)$ a higher ALP activity than monolayers. These results showed that the micromass system reduced the proliferation and increased the differentiation as compared to the standard monolayer system. In addition, the supplementation of the growth medium with $20 \mathrm{mM} \mathrm{Cr}$ had a stimulatory effect on the ALP activity, which is in accordance with the stimulatory effect on the metabolic activity. However, this high concentration had had an adverse effect on the viability.

\section{Morphology}

At 1 week nearly every cell under all conditions was histochemically positive for ALP activity (data not shown). The cells in monolayer cultures were confluent. There was no obvious difference visible between the control and the groups supplemented with $\mathrm{Cr}$ at 1 week (data not shown). At 2 weeks, the cells in monolayer (Fig. 3) and micromass cultures (Fig. 4) of all groups formed dense ALP positive and calcified nodules, which were more prominent at 3 weeks. In micromass cultures, the cells were migrating form the originally inoculated drop of cells towards the periphery of the culture dish (Fig. 4). In the control groups of both monolayer and micromass cultures the histochemical staining for ALP activity and calcification was less obvious than in the experimental groups at 2 and 3 weeks. Image analysis showed that both experimental groups of 10 and $20 \mathrm{mM} \mathrm{Cr}$ had significantly more calcified area in the monolayer and micromass cultures respectively, compared to the control group (Fig. 5). The 

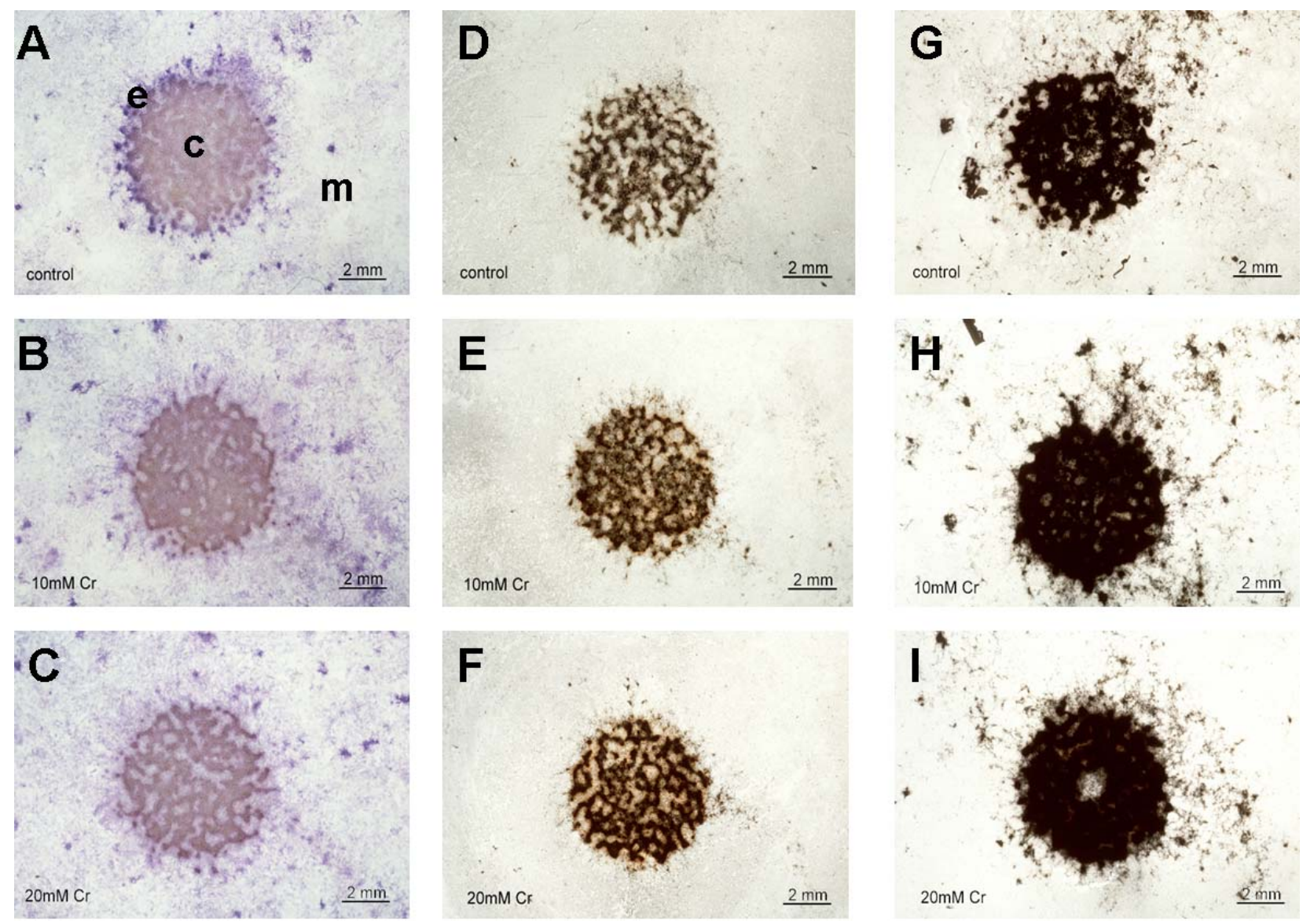

Figure 4. Histochemical staining of ALP activity and detection of calcification visualized by von Kossa staining in micromass cultures of osteoblast-like cells at 2, and 3 weeks, cultured in the absence (control) and presence of $10 \mathrm{mM}$ or $20 \mathrm{mM}$ of creatine (Cr). ALP activity is shown in blue and mineralization in black. There was no counterstaining of the cells. Note the staining is stronger in the $\mathrm{Cr}$ groups than in the control. A: ALP activity of control group at 2 weeks. B: ALP activity of $10 \mathrm{mM}$ Cr group at 2 weeks. C: ALP activity of $20 \mathrm{mM} \mathrm{Cr}$ group at 2 weeks. D: Mineralization of control group at 2 weeks. E: Mineralization of $10 \mathrm{mM} \mathrm{Cr}$ group at 2 weeks. F: Mineralization of $20 \mathrm{mM}$ Cr group at 2 weeks. G: Mineralization of control group at 3 weeks. H: Mineralization of $10 \mathrm{mM}$ Cr group at 3 weeks. I: Mineralization of $20 \mathrm{mM} \mathrm{Cr}$ group at 3 weeks. The centre of the originally inoculated drop of cells (c) and border (e), cells migrating away from the centre (m) towards the periphery.

values of the control and the $10 \mathrm{mM} \mathrm{Cr}$ groups were slightly higher at 3 weeks than at 2 weeks, but the difference was non significant in monolayer cultures. In contrast, in micromass cultures all values significantly increased over time (Fig. 5B). Thus, the morphological and histochemical findings, showing a positive effect of $\mathrm{Cr}$ for ALP activity staining, were fully in agreement with the biochemical results (see above).

\section{TEM-Ultrastructure}

The ultrastructure of the cells in the nodular area was similar in all groups. In all groups there was collagen production and mineralization (Fig. 6). At the interface between the bottom of the culture dish and the first cell layer, some fuzzy electron dense material but hardly any collagen was visible (not shown). In this area, there were often some dead cells found in all groups (not shown).

The cells were elongated except for the cells in the top layer, which were oval in shape and often had cell blebs (not shown). The cells displayed many cell-cell contacts either as focal points or with longer cell membranes in very close apposition to each other, as well as many cell processes, which were mainly parallel to the culture dish surface (not shown). In addition, cells had a well developed rough endoplasmatic reticulum (rER), which was dilated in some cells and many free ribosomes (Fig. 7). Mitochondria were numerous and of various sizes and shapes, ranging from round to banana-shaped (Fig. 7). It was observed that the $\mathrm{Cr}$ groups on average showed structurally better preserved mitochondria (Fig. 7B, arrows) than the control group, where often swollen mitochondria could be seen (Fig. 7B, arrow heads). The Golgi area and the vesicles were also numerous. They were either small or large, of regular or irregular shape, and their contents were electron lucent or electron dense (Fig. 7). There were coated pino/exocytotic vesicles fused with the plasma membrane and the cytoskeleton consisted of many microfilaments (not shown). In many cells there was as a dense area of microfilaments running parallel to the plasma membrane (not shown).

The bulk of the collagen fibrils were found in the middle to upper cell layers (Fig. 6). They were often found in membrane folds within the cells or cell processes (Fig. 8 ). The diameters of the fibrils in the membrane folds and 

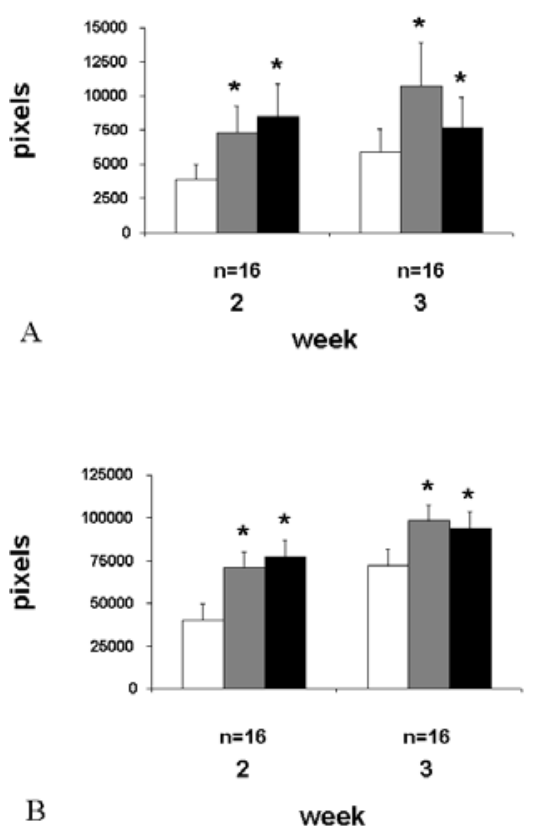

Figure 5. Quantification of mineralized area in monlayer and micromass cultures of osteoblast-like cells at 2 and 3 weeks, cultured in the absence (control) and presence of $10 \mathrm{mM}$ or $20 \mathrm{mM}$ of creatine $(\mathrm{Cr})$. A. Monolayer culture. Note: control significantly $(p<0.0015, p<0.0075)$ less calcified area than 10 and $20 \mathrm{mM} \mathrm{Cr}$ groups. B. Micromass culture. Note: control significantly $(\mathrm{p}<0.0001)$ less calcified area than 10 and $20 \mathrm{mM} \mathrm{Cr}$ group; significant $(p<0.0001)$ increase over time. Control cells grown in medium with low serum concentration (white columns). Cells grown under the same conditions plus $10 \mathrm{mM} \mathrm{Cr}$ (grey columns) and cells grown with supplementation of $20 \mathrm{mM} \mathrm{Cr}$ (black columns). Data are expressed as least squares means $+1.96 \mathrm{x}$ standard error.

the ones deeper in the matrix were rather similar (Fig. 8). The collagen fibrils were orthogonally oriented (Fig. 6; Fig. 8). Typically, they were either cut in cross sections or longitudinally. The characteristic cross-striation was clearly seen. The diameter of the fibrils was quite uniform in the unmineralized area (Fig. 6; Fig. 8). In the area of mineralization, the diameter of collagen fibrils varied and mineralized patches could be seen (Fig. 8). Matrix vesicles in the extracellular matrix were also found (Fig. 8).

No other obvious differences were observed between the control and experimental groups by conventional electron microscopy, although no quantitative statistical comparison was made at the ultrastructural level. However, the $\mathrm{Cr}$ groups tended to generally display better preserved mitochondria and more collagen fibrils within membrane folds than the control.

\section{Discussion}

This study showed that $\mathrm{Cr}$ had clear stimulatory effects on metabolic activity, differentiation of primary rat osteoblastlike cells, as well as on the mineral deposition by these cells. The extent and timing of this stimulation by $\mathrm{Cr}$ was, however, dependent on the cell culture system used, e.g.

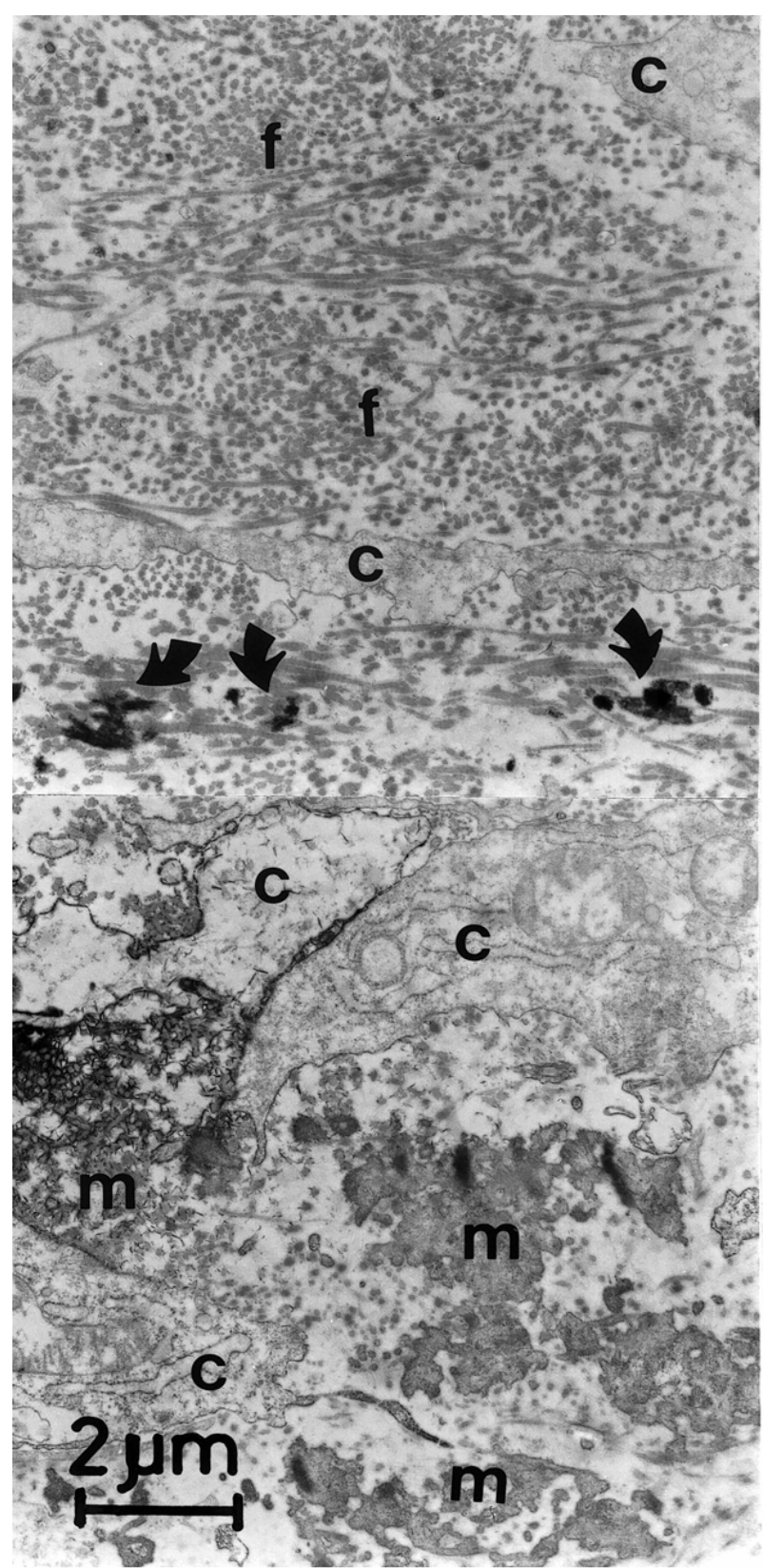

Figure 6. Ultrastructure of a mineralizing area in monolayer cultures. The cells (c) were surrounded by abundant collagen fibrils, which were orthogonally oriented (f). In the unmineralized area, there were single mineralized patches (arrow). Deeper in the matrix more heavily mineralized zones were evident (m).

whether osteoblast-like cells were cultured as monolayer or as micromass, the concentration of $\mathrm{Cr}$ added to the growth medium, as well as the time in culture.

The cells were sensitive to the culture system used. In the micromass system cell proliferation was reduced but differentiation was promoted, as compared to the standard monolayer system under serum-reduced conditions. Similar observations were made in the presence of $10 \%$ fetal calf serum in the growth medium (Gerber and ap Gwynn, 2001; Gerber and ap Gwynn, 2002). Micromass culture represent an organoid culture system promoting the formation of cell-cell contacts at the onset of culture 

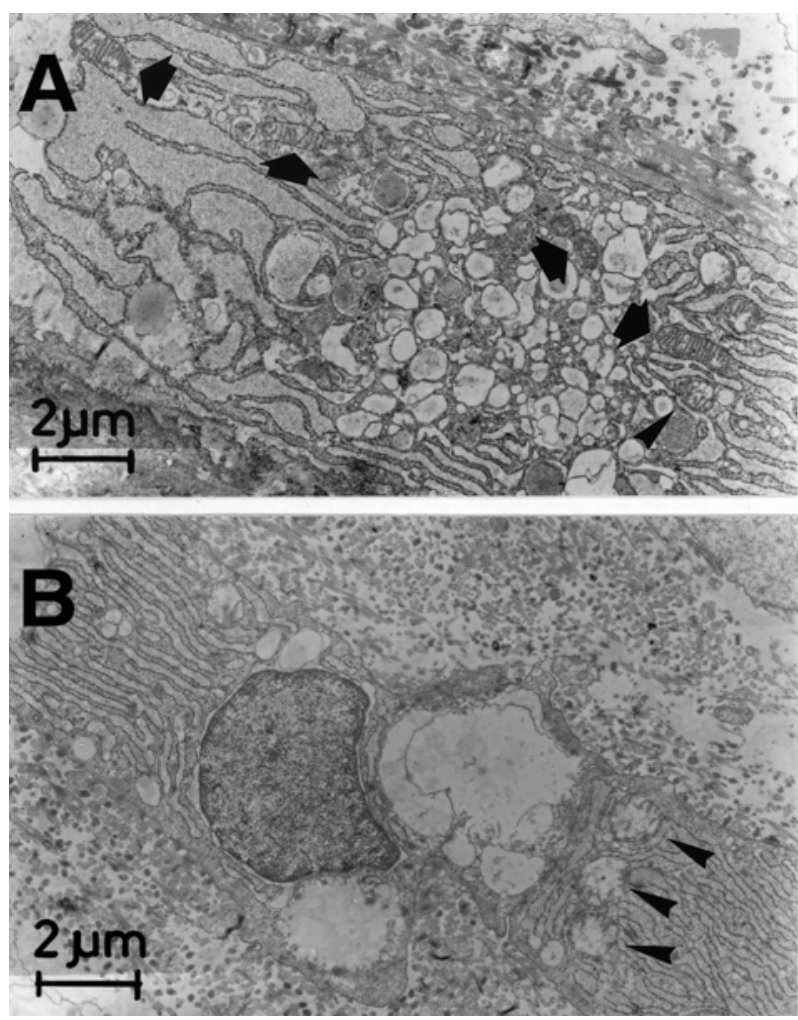

Figure 7 Ultrastructure of mitochondria in monolayer cultures. A: $10 \mathrm{mM} \mathrm{Cr}$ group with well preserved mitochondria (arrow) and other mitochondria (arrow head). B: Swollen mitochondria in the control group (arrow head).
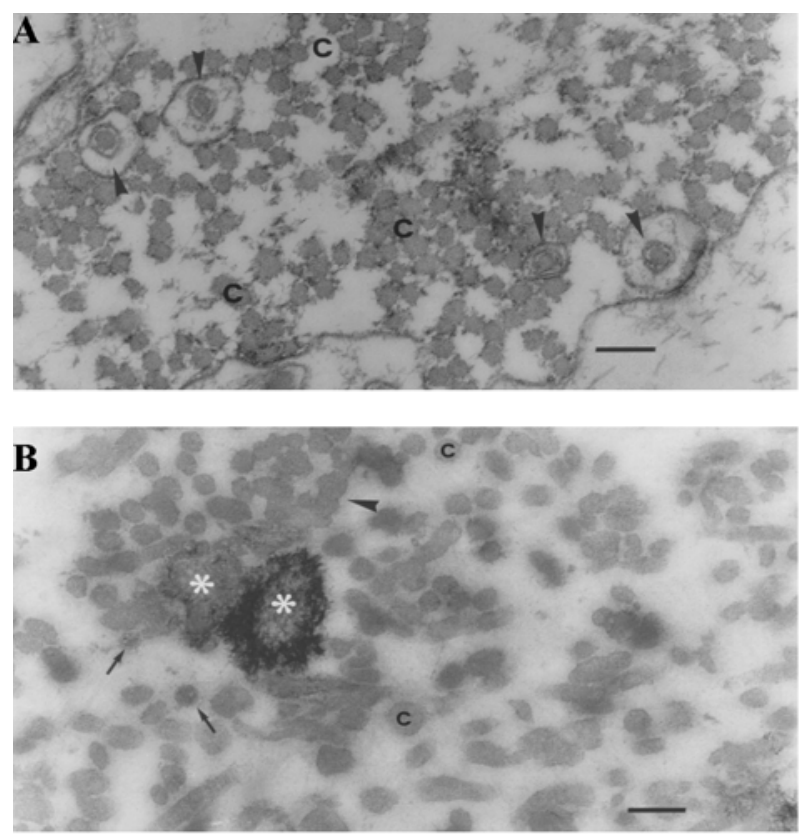

Figure 8. Ultrastructure of extracellular matrix in monolayer cultures. A: $10 \mathrm{mM} \mathrm{Cr}$ group. Collagen fibrils in membrane folds (arrow) have a similar diameter as the collagen fibrils in the matrix (c). B: control group. Mineralized patches (star) within collagen fibrils (c), which had a variable diameter and some were in very close contact (arrow head) and matrix vesicles (arrows). Bar $=150 \mathrm{~nm}$. and this resembles in many aspect the condensation process observed during intramembranous bone formation in vivo where mesenchymal progenitors condense and directly differentiate into osteoblasts (Hall, 1987).

There were no differences observed in the ultrastructure of the cells when they are kept under low serum concentration as compared to the addition of $10 \%$ FCS (Gerber and ap Gwynn, 2001; Gerber and ap Gwynn, 2002). Additionally, many collagen fibrils were found within membrane folds, which resembled the extracellular fibrils in diameter, staining pattern, and electron density. These are also previously described in rat osteoblasts (Gerber and ap Gwynn, 2002) as well as in tendon fibroblasts (Trelstad and Hayashi, 1979).

Supplementation of the growth medium with $\mathrm{Cr}$ in monolayer cultures slightly increased proliferation and clearly stimulated metabolic activity, ALP activity and mineralization. This was in contrast to what was observed in micromass cultures, where $\mathrm{Cr}$ promoted ALP activity and mineralization, but not metabolic activity. The beneficial effects of $\mathrm{Cr}$ on ALP activity were more pronounced at the higher concentration of $20 \mathrm{mM} \mathrm{Cr}$. However, this high concentration showed also some adverse effects on the viability of rat calvarial osteoblastlike cells at 3 weeks. This reduction in the viability might represent a general cell culture artefact and a dose response of the cells to $\mathrm{Cr}$ supplementation. As the cells proliferate, differentiate and form nodules, there is an increase in cell density, extracellular matrix and mineralization. This could lead to cell death as the diffusion of nutrients to the cells, which are localized near the culture dish surface and within the nodules, is reduced. These findings were supported by the ultrastructure of the cells in monlayers, where in most cases also some dead cells were observed within the nodules of all groups at 3 weeks. There was a dose response to the higher concentration of $20 \mathrm{mM} \mathrm{Cr}$, which significantly reduced the viability of the cells as compared to control and $10 \mathrm{mM} \mathrm{Cr}$ group. This effect was less pronounced in monolayer cultures. Presumably, the presence of dead cells could lead to an increased mineralization (Boskey et al., 1991).

Although $20 \mathrm{mM}$ Cr reduced the viability of the cells, it exerted significant stimulatory effects on metabolic activity and differentiation. This is in accordance to other in vitro studies, where protective effects of $10 \mathrm{mM} \mathrm{Cr}$ against inhibition of mitochondrial respiration by methylglyoxal could be shown in cardiac cells (Roy et al., 2003) and where $20 \mathrm{mM} \mathrm{Cr}$ improved intracellular $\mathrm{Ca}^{2+}$ handling and survival of mdx-mouse muscle cells (Pulido et al., 1998). In addition, protection of Cr pre-treatment in ischemia of mammalian neurons was maximal with $10 \mathrm{mM}$ $\mathrm{Cr}$ and no additional protection was provided by up to $20 \mathrm{mM} \mathrm{Cr}$ (Zapara et al., 2004). On the other hand, the addition of up to $50 \mathrm{mM} \mathrm{Cr}$ had no influence in proliferation of Hodgkin disease-derived tumor cell lines (Kornacker et al., 2001). Thus, if any negative effects by 
high concentrations of $\mathrm{Cr}$ were exerted on cells in culture, such effects seem to strongly depend on the kind of cells that are used.

The importance of cellular energy for proper functioning of bone and cartilage cells is corroborated by the fact that interventions that interfere with ATP generation in these cells, either in culture or within intact bone, have dramatic effects, e.g. inhibition of glycolysis causes both a reduction in collagen synthesis (Ramp et al., 1994) and a hypermineralization in tibiae of chick embryos (Ramp, 1975). For example, acute treatment of mature osteoblasts with metabolic inhibitors showed that the rate of glycolysis rose to maintain the cellular energy supply constant (Komarova et al., 2000) and pyruvate deficiency in cultured calvarial osteoblasts during proliferation caused cell death (Hinoi et al., 2002). On the other hand, inhibition of the activity of NAD-dependent enzymes associated with the production of ATP impairs cartilage formation resulting in limb shortening (Sheffield and Seegmiller, 1980). Furthermore, administration of b-guanidinopropionic acid (GPA; a Cr analogue and competitor of $\mathrm{Cr}$ uptake into the cell), which leads to a drastic reduction of intracellular $\mathrm{PCr}$ and $\mathrm{Cr}$ levels and thus interferes with the CK system, results in a disturbed enchondral bone formation in vivo and in vitro (Funanage et al., 1992). These data, obtained by Cr-depletion with GPA, stress the importance of the $\mathrm{CK} / \mathrm{PCr}$ system for normal bone and cartilage formation and physiological function. The fact that $\mathrm{Cr}$ has been shown to stimulate oxidative phosphorylation of isolated mitochondria that contain $\mathrm{CK}$, thus increasing the net production of $\mathrm{PCr}$, (Kay et al., 2000), would indicate that increasing total $\mathrm{Cr}$ levels in a given cell leads to a generally increased availability of ATP, as shown for example in muscle cells (Wyss and Wallimann, 1992). In cartilage and bone, $\mathrm{Cr}$ may exert similar cell protective effects as described in muscle (Pulido et al., 1998) and neuronal cells (Brewer and Wallimann, 2000) for review see (Wyss and Schulze, 2002) by improving the cellular energy state (higher PCr levels), and keeping the thermodynamic efficiency of ATP consuming processes, e.g. $\mathrm{Ca}^{2+}$ homeostasis high (high local ATP/ADP ratios) (Pulido et al., 1998; Wallimann et al., 1999; Passaquin et al., 2002), by stimulating mitochondrial respiration (Kay et al., 2000) and by protecting mitochondria from going into permeability transition and swelling (O'Gorman et al., 1997; Dolder et al., 2001; Dolder et al., 2003; Speer et al., 2005), that would eventually lead to cell death by apoptosis. As observed here, Cr supplemented osteoblast-like cells showed morphologically better preserved, less swollen mitochondria compared to controls without $\mathrm{Cr}$. This finding is supported by the recent observations that the presence of mitochondrial CK together with $\mathrm{Cr}$ stabilized mitochondrial contact sites between inner and outer mitochondrial membranes, thus preventing swelling (Speer et al., 2005). Thus, besides improving cellular energetics via an elevation of the $\mathrm{PCr} / \mathrm{ATP}$ ratio, some effects of $\mathrm{Cr}$ observed here in osteoblast-like cells may additionally be related to protective effects of $\mathrm{Cr}$ on mitochondrial structure and function.
Precise coupling of spatially separated intracellular ATP-producing and ATP-consuming processes is fundamental to the bioenergetics of living organisms. The $\mathrm{CK} / \mathrm{PCr}$ circuit ensures a fail-safe operation of these energetic systems over a broad range of cellular functional activities by stabilizing cellular ATP levels and keeping ATP/ADP ratio low (Dzeja and Terzic, 2003). As Cr supplementation increases intracellular $\mathrm{PCr} / \mathrm{ATP}$ ratios, cellular energetics are additional stabilized (Wallimann et al., 1992). Interestingly, Cr supplementation also increases glucose oxidation and phosphorylation of AMP-activated protein kinase (AMPK), and at the same time reduces lactate production in L6 rat skeletal muscle cells (Ceddia et al., 2004). Thus, some effects of $\mathrm{Cr}$ on osteoblast-like cells could also be mediated by $\mathrm{Cr}$ affecting AMPK as an intracellular energy sensor that helps to maintain cellular energy balance by keeping ATP concentration stable within the cell (for review see Carling, 2004). Indeed, ATP availability and ATPase activity parallel the metabolic activity, viability and matrix synthesis of osteoblasts (Heyden and From, 1970; Tonna and Severson, 1971). This fact and the various mechanisms of action of $\mathrm{Cr}$ (see above) may explain the possible effects of $\mathrm{Cr}$ supplementations observed here.

In conclusion, micromass culture promotes the differentiation of primary osteoblast-like cells over monolayer cultures by decreasing proliferation and by increasing ALP activity and mineralization. The observed stimulatory effects of external supplementation with the energy precursor, $\mathrm{Cr}$, were dependent on the organizational level of the cells in such a way that osteoblast-like cells in monolayer culture showed a significantly increased metabolic activity, ALP activity and mineralization in the presence of $\mathrm{Cr}$ in the growth medium. In micromass culture, $\mathrm{Cr}$ also significantly enhanced ALP activity and mineralization over the control group. The effect on ALP activity was more pronounced at the higher concentration of $\mathrm{Cr}$, but $20 \mathrm{mM} \mathrm{Cr}$ had some adverse effects on the viability.

Based on this study and the literature, it is clear that cellular energetic is important for bone development, differentiation and maintenance and thus directly related to osteoporosis. Thus $\mathrm{Cr}$ supplementation could possibly used as adjuvant therapy for bone fracture healing or within a regime of osteoporosis treatment.

\section{Acknowledgments}

We thank Dr. Dominik Pfluger for the statistical analysis and would like to express our gratitude to all members of the Wallimann research group for support, help and discussion.

This research was supported by the AO ASIF Foundation, by the EMDO Foundation Zurich (to I.G) and by grants from the Swiss Society for Research on Muscle Diseases (to T.W.) and the Swiss National Science Foundation (NSF, grant No. 31-50824.97 and No. 3162024.00 to T.W.) and Swiss National Science Foundation NFP-53 Grant 4053040-104856/1 (to T.W. and I.G) 


\section{References}

Aldini NN, Fini M, Giavaresi G, Torricelli P, Martini L, Giardino R, Ravaglioli A, Krajewski A, Mazzocchi M, Dubini B, Ponzi-Bossi MG, Rustichelli F, Stanic V (2002) Improvement in zirconia osseointegration by means of a biological glass coating: An in vitro and in vivo investigation. J Biomed Mater Res 61: 282-289.

Baker SK, Tarnopolsky MA (2003) Targeting cellular energy production in neurological disorders. Expert Opin Investig Drugs 12: 1655-1679.

Bender A, Auer DP, Merl T, Reilmann R, Saemann P, Yassouridis A, Bender J, Weindl A, Dose M, Gasser T, Klopstock T (2005) Creatine supplementation lowers brain glutamate levels in Huntington's disease. J Neurol 252: 36-41.

Boskey AL, Doty SB, Binderman I (1994) Adenosine 5'-triphosphate promotes mineralization in differentiating chick limb-bud mesenchymal cell cultures. Microsc Res Tech 28: 492-504.

Boskey AL, Stiner D, Doty SB, Binderman I (1991) Requirement of vitamin $\mathrm{C}$ for cartilage calcification in a differentiating chick limb-bud mesenchymal cell culture. Bone 12: 277-282.

Brewer GJ, Wallimann TW (2000) Protective effect of the energy precursor creatine against toxicity of glutamate and beta-amyloid in rat hippocampal neurons. J Neurochem 74: 1968-1978.

Burks JK, Peck WA (1979) Growth and differentiation of isolated calvarium cells in a serum-free medium. Int Rev Cytol Suppl 10: 103-115.

Carling D (2004) The AMP-activated protein kinase cascade - a unifying system for energy control. Trends Biochem Sci 29: 18-24.

Cartier P (1969) [Aerobic metabolism and mineralisation of bone tissue]. Bull Soc Chim Biol (Paris) 50: 1819-1832.

Ceddia R, Sweeney G, Carling D (2004) Creatine increases glucose oxidation and AMPK phosphorylation and reduces lactate production in L6 rat skeletal muscle cells. The AMP-activated protein kinase cascade-a unifying system for energy control. J Physiol 555: 409421.

Ciapetti G, Granchi D, Savarino L, Cenni E, Magrini E, Baldini N, Giunti A (2002) In vitro testing of the potential for orthopedic bone cements to cause apoptosis of osteoblast-like cells. Biomaterials 23: 617-627.

Dolder M, Walzel B, Speer O, Schlattner U, Wallimann $\mathrm{T}$ (2003) Inhibition of the mitochondrial permeability transition by creatine kinase substrates. Requirement for microcompartmentation. J Biol Chem 278: 17760-17766.

Dolder M, Wendt S, Wallimann T (2001) Mitochondrial creatine kinase in contact sites: interaction with porin and adenine nucleotide translocase, role in permeability transition and sensitivity to oxidative damage. Biol Signals Recept 10: 93-111.

Dzeja PP, Terzic A (2003) Phosphotransfer networks and cellular energetics. J Exp Biol 206: 2039-2047.

Fini M, Giavaresi G, Torricelli P, Giardino R (2001) Pericellular partial oxygen pressure $\left(\mathrm{pO}_{2}\right)$ measurement in osteopenic bone-derived osteoblast cultures. Artif Cells Blood Substit Immobil Biotechnol 29: 213-223.

Funanage VL, Carango P, Shapiro IM, Tokuoka T, Tuan RS (1992) Creatine kinase activity is required for mineral deposition and matrix synthesis in endochondral growth cartilage. Bone Miner 17: 228-236.

Gerber I, ap Gwynn I (2001) Influence of cell isolation, cell culture density, and cell nutrition on differentiation of rat calvarial osetoblast-like cells in vitro. Eur Cell Mater 2: $10-20$.

Gerber I, ap Gwynn I (2002) Differentiation of rat osteoblast-like cells in monolayer and micromass cultures. Eur Cell Mater 3: 19-30.

Granstrom G (1986) Isoenzyme changes during rat facial development. Scand J Dent Res 94: 1-14.

Gray TK (1989) Estrogens and the skeleton: cellular and molecular mechanisms. J Steroid Biochem 34: 285287.

Guerrero-Ontiveros ML, Wallimann T (1998) Creatine supplementation in health and disease. Effects of chronic creatine ingestion in vivo: down-regulation of the expression of creatine transporter isoforms in skeletal muscle. Mol Cell Biochem 184: 427-437.

Hall BK (1987) Earliest evidence of cartilage and bone development in embryonic life. Clin Orthop Relat Res 225: 255-272.

Hespel P, Eijnde BO, Van Leemputte M, Urso B, Greenhaff PL, Labarque V, Dymarkowski S, Van Hecke P, Richter EA (2001) Oral creatine supplementation facilitates the rehabilitation of disuse atrophy and alters the expression of muscle myogenic factors in humans. $\mathrm{J}$ Physiol 536: 625-633.

Heyden G, From SH (1970) Enzyme histochemistry and its application in comparative studies of adenosinetriphosphatase (ATPase) and some oxidative enzymes in bone, cartilage and tooth germs. Odontol Revy 21: 129-142.

Hinoi E, Fujimori S, Takemori A, Yoneda Y (2002) Cell death by pyruvate deficiency in proliferative cultured calvarial osteoblasts. Biochem Biophys Res Commun 294: 1177-1183.

Hobson GM, Funanage VL, Elsemore J, Yagami M, Rajpurohit R, Perriard JC, Hickok NJ, Shapiro IM, Tuan RS (1999) Developmental expression of creatine kinase isoenzymes in chicken growth cartilage. J Bone Miner Res 14: 747-756.

Hoffman RM (1994) Three-dimensional sponge-gel matrix histoculture: methods and applications. In: Celis JE (ed) Cell Biology: a Laboratory Handbook. Academic Press, San Diego, pp 365-379.

Ipsiroglu OS, Stromberger C, Ilas J, Hoger H, Muhl A, Stockler-Ipsiroglu S (2001) Changes of tissue creatine concentrations upon oral supplementation of creatinemonohydrate in various animal species. Life Sci 69: 18051815.

Kakuta S, Golub EE, Haselgrove JC, Chance B, Frasca P, Shapiro IM (1986) Redox studies of the epiphyseal growth cartilage: pyridine nucleotide metabolism and the development of mineralization. J Bone Miner Res 1: 433440 . 
Katoh R, Iyoda K, Oohira A, Kato K, Nogami H (1991) Zonal and age-related difference in the amounts of creatine kinase subunits in cartilage. Clin Orthop Relat Res 271: 283-287.

Kay L, Nicolay K, Wieringa B, Saks V, Wallimann T (2000) Direct evidence for the control of mitochondrial respiration by mitochondrial creatine kinase in oxidative muscle cells in situ. J Biol Chem 275: 6937-6944.

Kaye AM, Weisman Y, Harell A, Somjen D (1990) Hormonal stimulation of bone cell proliferation. J.Steroid Biochem Mol Biol 37: 431-435.

Komarova SV, Ataullakhanov FI, Globus RK (2000) Bioenergetics and mitochondrial transmembrane potential during differentiation of cultured osteoblasts. Am J Physiol Cell Physiol 279: C1220-1229.

Kornacker M, Schlattner U, Wallimann T, Verneris MR, Negrin RS, Kornacker B, Staratschek-Jox A, Diehl V, Wolf J (2001) Hodgkin disease-derived cell lines expressing ubiquitous mitochondrial creatine kinase show growth inhibition by cyclocreatine treatment independent of apoptosis. Int J Cancer 94: 513-519.

Kvam BJ, Pollesello P, Vittur F, Paoletti S (1992) 31P NMR studies of resting zone cartilage from growth plate. Magn Reson Med 25: 355-361.

Labarca C, Paigen K (1980) A simple, rapid, and sensitive DNA assay procedure. Anal Biochem 102: 344352.

Lindl T, Bauer J (1994) Inhibition des Zellwachstums (quantitative Neutralmethode). (Inhibition of cell growth (quantitative neutral method)). In: Lindl $\mathrm{T}$ and Bauer J (eds) Zell- und Gewebekultur (Cell and Tissue Culture). Gustav Fischer Verlag, Stuttgart Jena New York, p 201.

Louis M, Lebacq J, Poortmans JR, Belpaire-Dethiou MC, Devogelaer JP, Van Hecke P, Goubel F, Francaux M (2003) Beneficial effects of creatine supplementation in dystrophic patients. Muscle Nerve 27: 604-610.

Mosmann T (1983) Rapid colorimetric assay for cellular growth and survival: application to proliferation and cytotoxicity assays. J Immunol Methods 65: 55-63.

Mujika I, Padilla S (1997) Creatine supplementation as an ergogenic acid for sports performance in highly trained athletes: a critical review. Int J Sports Med 18: 491-496.

O’Gorman E, Beutner G, Dolder M, Koretsky AP, Brdiczka D, Wallimann T (1997) The role of creatine kinase in inhibition of mitochondrial permeability transition. FEBS Lett 414: 253-257.

Ono Y, Kato K, Oohira A, Katoh R, Nogami H (1994) Cell function during chondrogenesis and osteogenesis induced by bone morphogenetic protein enclosed in diffusion chamber. Biochemical studies on native products derived from outside differentiating cells. Clin Orthop Relat Res 298: 305-312.

Passaquin AC, Renard M, Kay L, Challet C, Mokhtarian A, Wallimann T, Ruegg UT (2002) Creatine supplementation reduces skeletal muscle degeneration and enhances mitochondrial function in $\mathrm{mdx}$ mice. Neuromuscul Disord 12: 174-182.

Persky AM, Brazeau GA (2001) Clinical pharmacology of the dietary supplement creatine monohydrate. Pharmacol Rev 53: 161-176.
Persky AM, Brazeau GA, Hochhaus G (2003) Pharmacokinetics of the dietary supplement creatine. Clin Pharmacokinet 42: 557-574.

Pollesello P, de Bernard B, Grandolfo M, Paoletti S, Vittur F, Kvam BJ (1991) Energy state of chondrocytes assessed by 31P-NMR studies of preosseous cartilage. Biochem Biophys Res Commun 180: 216-222.

Pulido SM, Passaquin AC, Leijendekker WJ, Challet C, Wallimann T, Ruegg UT (1998) Creatine supplementation improves intracellular $\mathrm{Ca}^{2+}$ handling and survival in mdx skeletal muscle cells. FEBS Lett 439: $357-$ 362 .

Rajpurohit R, Mansfield K, Gao X, Shapiro IM (1998) Creatine kinase activity and cartilage energy metabolism: creatine kinase-creatine phosphate circuit activity and macromolecule synthesis. Cells and Materials 8: 73-82.

Ramires PA, Romito A, Cosentino F, Milella E (2001) The influence of titania/hydroxyapatite composite coatings on in vitro osteoblasts behaviour. Biomaterials 22: 14671474.

Ramp WK (1975) Cellular control of calcium movements in bone. Interrelationships of the bone membrane, parathyroid hormone and alkaline phosphatase. Clin Orthop Relat Res 106: 311-322.

Ramp WK, Lenz LG, Kaysinger KK (1994) Medium $\mathrm{pH}$ modulates matrix, mineral, and energy metabolism in cultured chick bones and osteoblast-like cells. Bone Miner 24: 59-73.

Reynolds ES (1963) The use of lead citrate at high $\mathrm{pH}$ as an electron opaque stain in electron microscopy. J Cell Biol 17: 208-212.

Roy SS, Biswas S, Ray M, Ray S (2003) Protective effect of creatine against inhibition by methylglyoxal of mitochondrial respiration of cardiac cells. Biochem J 372: 661-669.

Saito S (1959) Studies on the mechanism of ossification in tissue culture. II. Effects of adenosinetriphosphate and phosphocreatine on the growth of chick embryo femur. Jpn J Exp Med 29: 91-106.

Shapiro IM, Debolt K, Funanage VL, Smith SM, Tuan RS (1992) Developmental regulation of creatine kinase activity in cells of the epiphyseal growth cartilage. J Bone Miner Res 7: 493-500.

Shapiro IM, Golub EE, Chance B, Piddington C, Oshima O, Tuncay OC, Frasca P, Haselgrove JC (1988) Linkage between energy status of perivascular cells and mineralization of the chick growth cartilage. Dev Biol 129: 372-379.

Sheffield VC, Seegmiller RE (1980) Impaired energy metabolism as an initial step in the mechanism for 6aminonicotinamide-induced limb malformation. J Embryol Exp Morphol 59: 217-222.

Sjovall K, Hansson LI (1971) The pattern of ATPcreatine phosphotransferase activity in growing long bones of new-born mice. Histochem J 3: 143-150.

Somjen D, Kaye AM (1994) Stimulation by insulinlike growth factor-I of creatine kinase activity in skeletalderived cells and tissues of male and female rats. J.Endocrinol 143: 251-259.

Somjen D, Kaye AM, Binderman I (1984a) 24R,25dihydroxyvitamin $\mathrm{D}$ stimulates creatine kinase $\mathrm{BB}$ activity 
in chick cartilage cells in culture. FEBS Lett 167: 281284.

Somjen D, Kaye AM, Binderman I (1985a) Stimulation of creatine kinase $\mathrm{BB}$ activity by parathyroid hormone and by prostaglandin E2 in cultured bone cells. Biochem J 225: 591-596.

Somjen D, Kaye AM, Rodan GA, Binderman I (1985b) Regulation of creatine kinase activity in rat osteogenic sarcoma cell clones by parathyroid hormone, prostaglandin E2, and vitamin D metabolites. Calcif Tissue Int 37: 635638.

Somjen D, Mor Z, Kaye AM (1994) Age dependence and modulation by gonadectomy of the sex-specific response of rat diaphyseal bone to gonadal steroids. Endocrinology 134: 809-814.

Somjen D, Vargas V, Waisman A, Wingender E, Tegge W, Kaye AM (1995) Stimulation of creatine kinase activity in rat skeletal tissue in vivo and in vitro by protease-resistant variants of parathyroid hormone fragments. Biochem $\mathrm{J}$ 309: 85-90.

Somjen D, Weisman Y, Binderman I, Kaye AM (1984b) Stimulation of creatine kinase BB activity by 1 alpha,25dihydroxycholecalciferol and 24R,25-dihydroxycholecalciferol in rat tissues. Biochem J 219: 1037-1041.

Somjen D, Weisman Y, Binderman I, Kaye AM (1984c) Stimulation of creatine kinase BB activity by 1 alpha,25dihydroxycholecalciferol and 24R,25-dihydroxycholecalciferol in rat tissues. Biochem J 219: 1037-1041.

Somjen D, Weisman Y, Mor Z, Harell A, Kaye AM (1991) Regulation of proliferation of rat cartilage and bone by sex steroid hormones. J Steroid Biochem Mol Biol 40: 717-723.

Somjen D, Zor U, Kaye AM, Harell A, Binderman I (1987) Parathyroid hormone induction of creatine kinase activity and DNA synthesis is mimicked by phospholipase C, diacylglycerol and phorbol ester. Biochim Biophys Acta 931: 215-223.

Speer O, Back N, Buerklen T, Brdiczka D, Koretsky A, Wallimann T, Eriksson O (2005) Octameric mitochondrial creatine kinase induces and stabilizes contact sites between the inner and outer membrane. Biochem J 385: 445-450.

Tarnopolsky MA, Parise G (1999) Direct measurement of high-energy phosphate compounds in patients with neuromuscular disease. Muscle Nerve 22: 1228-1233.

Tonna EA, Severson AR (1971) Changes in localization and distribution of adenosine triphosphatase activity in skeletal tissues of the mouse concomitant with aging. J Gerontol 26: 186-193.

Torricelli P, Fini M, Giavaresi G, Borsari V, Carpi A, Nicolini A, Giardino R (2003) Comparative interspecies investigation on osteoblast cultures: data on cell viability and synthetic activity. Biomed Pharmacother 57: 57-62.

Trelstad RL, Hayashi K (1979) Tendon collagen fibrillogenesis: intracellular subassemblies and cell surface changes associated with fibril growth. Dev Biol 71: 228242.

Vorgerd M, Grehl T, Jager M, Muller K, Freitag G, Patzold T, Bruns N, Fabian K, Tegenthoff M, Mortier W, Luttmann A, Zange J, Malin JP (2000) Creatine therapy in myophosphorylase deficiency (McArdle disease): a placebo-controlled crossover trial. Arch Neurol 57: 956963.

Wallimann T, Hemmer W (1994) Creatine kinase in non-muscle tissues and cells. Mol Cell Biochem 133-134: 193-220.

Wallimann T, Wyss M, Brdiczka D, Nicolay K, Eppenberger HM (1992) Intracellular compartmentation, structure and function of creatine kinase isoenzymes in tissues with high and fluctuating energy demands: the 'phosphocreatine circuit' for cellular energy homeostasis. Biochem J 281: 21-40.

Wallimann T, Schlattner U, Guerrero L, Dolder M (1999) The phosphocreatine circuit and creatine supplementation, both come of age. In: Mori A, Ishida M, Clark JF (eds) Guanidino Compounds in Biology and Medicine. Blackwell Science, Japan, p 117-129.

Walter MC, Reilich P, Lochmuller H, Kohnen R, Schlotter B, Hautmann H, Dunkl E, Pongratz D, MullerFelber W (2002) Creatine monohydrate in myotonic dystrophy: a double-blind, placebo-controlled clinical study. J Neurol 249: 1717-1722.

Wyss M, Kaddurah-Daouk R (2000) Creatine and creatinine metabolism. Physiol Rev 80: 1107-1213.

Wyss M, Schulze A (2002) Health implications of creatine: can oral creatine supplementation protect against neurological and atherosclerotic disease? Neuroscience 112: $243-260$.

Wyss M, Wallimann T (1992) Metabolite channelling in aerobic energy metabolism. J Theor Biol 158: 129-132.

Wyss M, Wallimann T (1994) Creatine metabolism and the consequences of creatine depletion in muscle. Mol Cell Biochem 133-134: 51-66.

Yang Y, Tian J, Deng L, Ong JL (2002) Morphological behavior of osteoblast-like cells on surface-modified titanium in vitro. Biomaterials 23: 1383-1389.

Zapara TA, Simonova OG, Zharkikh AA, Balestrino M, Ratushniak AS (2004) Seasonal differences and protection by creatine or arginine pretreatment in ischemia of mammalian and molluscan neurons in vitro. Brain Res 1015: 41-49.

\section{Discussion with Reviewers}

J. Gasser: The authors point at the importance of a good cell viability with examples from the literature. According to their work, creatine at $20 \mathrm{mM}$ decreases cellular viability. Have the authors tested in their system whether creatine induces cell apoptosis (caspase activity for example)?

Authors: So far we have not done this yet, but we plan to do it in the near future. The ultrastructure of the cells is the only information we have at the present time addressing your question of whether apoptosis is taking place or not. There were, however, no indications of more dead cells being present in the $20 \mathrm{mM}$ creatine group than in the 10 $\mathrm{mM}$ creatine group or in the control group. Under all conditions, dead cells were found at 3 weeks, which is in accordance with the literature. There is abundant literature concerning necrosis and apoptosis during bone formation 
in vivo and in vitro. In this study, $\mathrm{Cr}$ treated cells showed better preserved mitochondria than the control group. One reason why $20 \mathrm{mM}$ creatine in the medium under the conditions used, may have had a slight effect on osteoblast cell viability may be an osmotic effect, since creatine is taken up by a specific creatine transporter that co-transports sodium and chloride together with creatine (co transport), which could lead, if creatine is taken up fast enough, to a short-time hyper osmotic condition.

To address the question of an osmotic effect, we performed a dose response curve of $\mathrm{Cr}$ under iso-osmotic conditions using human osteoblast-like cells (HOB) in vitro. The concentrations of $\mathrm{Cr}$ were ranging from 1 to 20 $\mathrm{mM}$. The osmolarity was adjusted to $20 \mathrm{mM}$ with mannitol in all groups. The standard growth medium was used as a control for the effects of mannitol alone. The cells were kept in culture for 2 weeks. The viability and metabolic activity were analysed by neutral red (NR) uptake and MTT assay, respectively. NR uptake and the MTT reduction of the cells kept either in the standard growth medium or in the standard medium with $20 \mathrm{mM}$ mannitol were similar. This shows that an increase in the osmotic pressure by the addition of $20 \mathrm{mM}$ mannitol had no effects on the viability and metabolic activity of HOB. Cr supplementation decreased the neutral red uptake of HOB in a dose dependent manner, where the $10 \mathrm{mM} \mathrm{Cr}$ group was significantly lower than the control, and $20 \mathrm{mM}$ Cr group was significantly lower than all tested concentrations of $\mathrm{Cr}$ and the standard growth medium alone. This was in contrast to the MTT reduction normalized to the neutral red uptake, which was significantly stimulated by the supplementation of the growth medium with $20 \mathrm{mM} \mathrm{Cr}$. These results clearly indicate that the observed reduction in the neutral red uptake and the stimulation of the metabolic activity were due to the addition of $\mathrm{Cr}$ and not to an increase in osmotic pressure.

J. Caverzasio: Is it possible that increased metabolic activity in cells exposed to creatine accelerates cell apoptosis and necrosis and that this might contribute to the higher mineralization that the authors observed?

Authors: We analysed the metabolic activity by using the MTT assay. MTT enters the cells by endocytosis. Most cellular MTT reduction occurs outside of the mitochondrial inner membrane and involves NADH and NADPHdependent mechanisms (Berridge and Tan, 1993). There is evidence that mitochondrial, cytosolic and microsomal enzymes reduce MTT (Gonzalez and Tarloff, 2001). Reduced MTT is then exocytosed and appears as needlelike crystals on the cell surface (Liu, 1999). A decrease in cellular MTT conversion does not necessarily mean cell death or cell growth inhibition, but can be influenced by factors, which have effects on endocytosis, cellular redox potential and exocytosis (Liu, 1999). In our study, $\mathrm{Cr}$ stimulated the MTT reduction, meaning that the cells supplemented with $\mathrm{Cr}$ could have a higher content of $\mathrm{NAD}(\mathrm{P}) \mathrm{H}$ than the control. Apoptosis of osteoblasts can be induced by NO as an example (Chen et al., 2002; Chen et al., 2005). The authors find, that NO release by sodium nitroprusside caused a time- and concentration-dependent decrease in MTT reduction and ALP activity and at the same time lead to an increase in the percentage of osteoblasts undergoing apoptosis by decreasing cellular ATP content, which leads to cell dysfunction. Similarly in myocytes, energy depletion induced by $\mathrm{KCN}$ and 2-deoxyD-glucose, induced a decrease in the $\mathrm{PCr} / \mathrm{ATP}$ ratio, as well as a MTT reduction concomitant with stimulated apoptosis (Engelbrecht et al., 2004). Furthermore, MTT reduction accurately determines apoptotic death of neurons (Lobner, 2000). These findings indicate that ATP depletion is an important factor for induction of apoptosis. As pointed out in the discussion, $\mathrm{Cr}$ has clear protective effects in other cell types on mitochondrial structure and function, which is a key element in the induction of apoptosis. In addition, MTT reduction and ALP activity were positively affected by $\mathrm{Cr}$ supplementation in our study. Therefore, it is rather unlikely that $\mathrm{Cr}$ supplementation itself could lead to apoptosis.

R. Oreffo: The physiological relevance of creatine concentrations advocated and effects observed are unclear could you comment on the significance for the bone community?

Authors: Some details concerning the concentrations of creatine used by other laboratories in relation to the ones applied here are indicated in the discussion. As the reviewer can see, we are using the same concentration, which may seem high at first glance, but considering that for example muscle tissue contains up to $50 \mathrm{mM}$ of intracellular total creatine concentration, the concentration range used here may seem appropriate.

Since bone is a non-muscle tissue, which contain generally between 5 and $20 \mathrm{mM}$ total creatine, the concentrations chosen in our experiments seem reasonable.

Bioenergetics may be a key element to understanding the changes observed in bone diseases such as osteoporosis. Deficient bone formation in metabolic bone diseases with a lower than normal osteoblastic population results from an impaired proliferative capacity of osteoblastic cells present along the trabecular bone surface (Marie and De Vernejoul, 1993). This could possibly be attributed to inhibition of glycolysis, which is the major energy source for immature osteoblasts (Komarova et al., 2000, text reference). Progressive differentiation coincides with changes in cellular metabolism and mitochondrial activity, which are likely to play key roles in osteoblast function (Komarova et al., 2000). Interestingly, osteoblasts derived from osteopenic rat bone show an increased respiration rate as compared to normal cells (Fini et al., 2001, text reference).

Maintenance of adult skeletal mass is controlled not only by changes in the production of osteoclasts and osteoblasts but also by altering the duration of their respective lifespan through regulated apoptosis (Weinstein and Manolagas, 2000). Osteoblast apoptosis has been shown to be important in the pathogenesis of certain metabolic bone diseases such as glucocorticoid-induced osteoporosis, postmenopausal osteoporosis and involutional osteoporosis (for review see Manolagas, 2000; Weinstein and Manolagas, 2000; Weinstein, 2001; Jilka, 
2003; Rehman and Lane, 2003). Furthermore, there could be a link between diabetes as major metabolic disease and bone formation as diabetic persons have a higher risk for osteoporosis than the average population (for review see Leidig-Bruckner and Ziegler, 2001; Chau et al., 2003).

Therapies that prevent or reverse osteoporosis act at least in part by preventing osteoblast apoptosis and/or by stimulating osteoclast apoptosis (Manolagas, 2000; Jilka, 2003). Thus, creatine may exert similar cell protective effects in bone as described in the discussion of the paper.

\section{Additional References}

Berridge MV, Tan AS (1993) Characterization of the cellular reduction of 3-(4,5-dimethylthiazol-2-yl)-2,5diphenyltetrazolium bromide (MTT): subcellular localization, substrate dependence, and involvement of mitochondrial electron transport in MTT reduction. Arch Biochem Biophys 303: 474-482.

Chau DL, Edelman SV, Chandran M (2003) Osteoporosis and diabetes. Curr Diab Rep 3: 37-42.

Chen RM, Chen TL, Chiu WT, Chang CC (2005) Molecular mechanism of nitric oxide-induced osteoblast apoptosis. J Orthop Res 23: 462-468.

Chen RM, Liu HC, Lin YL, Jean WC, Chen JS, Wang JH (2002) Nitric oxide induces osteoblast apoptosis through the de novo synthesis of Bax protein. J Orthop Res 20: 295-302.

Engelbrecht AM, Niesler C, Page C, Lochner A (2004) p38 and JNK have distinct regulatory functions on the development of apoptosis during simulated ischaemia and reperfusion in neonatal cardiomyocytes. Basic Res Cardiol 99: $338-350$.

Gonzalez RJ, Tarloff JB (2001) Evaluation of hepatic subcellular fractions for Alamar blue and MTT reductase activity. Toxicol In Vitro 15: 257-259.

Jilka RL (2003) Biology of the basic multicellular unit and the pathophysiology of osteoporosis. Med Pediatr Oncol 41: 182-185.

Leidig-Bruckner G, Ziegler R (2001) Diabetes mellitus a risk for osteoporosis? Exp Clin Endocrinol Diabetes 109 (Suppl 2): S493-S514.

Liu Y (1999) Understanding the biological activity of amyloid proteins in vitro: from inhibited cellular MTT reduction to altered cellular cholesterol homeostasis. Prog Neuropsychopharmacol Biol Psychiatry 23: 377-395.

Lobner D (2000) Comparison of the LDH and MTT assays for quantifying cell death: validity for neuronal apoptosis? J Neurosci Methods 96: 147-152.

Manolagas SC (2000) Birth and death of bone cells: basic regulatory mechanisms and implications for the pathogenesis and treatment of osteoporosis. Endocr Rev 21: 115-137.

Marie PJ, De Vernejoul MC (1993) Proliferation of bone surface-derived osteoblastic cells and control of bone formation. Bone 14: 463-468.

Rehman Q, Lane NE (2003) Effect of glucocorticoids on bone density. Med Pediatr Oncol 41: 212-216.

Weinstein RS (2001) Glucocorticoid-induced osteoporosis. Rev Endocr Metab Disord 2: 65-73.

Weinstein RS, Manolagas SC (2000) Apoptosis and osteoporosis. Am J Med 108: 153-164. 